\title{
Spectroscopic Studies on the inclusion complex formation between 2,4- dihydroxyquinoline and cyclodextrin derivatives
}

\author{
Huda Mahmoud ${ }^{1}$, Ahmed Alazaly ${ }^{1}$, Hany H. Monir ${ }^{2}$, Hesham S. Abdel-Samad*1 ${ }^{1}$ and \\ Ayman A. Abdel-Shafi ${ }^{1}$ \\ ${ }^{1}$ Department of Chemistry, Faculty of Science, Ain Shams University, 11566 Abbassia, Cairo, \\ Egypt. \\ ${ }^{2}$ Analytical Chemistry Department Faculty of Pharmacy, Cairo University.
}

\begin{abstract}
Inclusion of 2,4-dihydroxyquinoline in a variety of cyclodextrins with different cavity dimensions is studied. It has been found that excited state proton transfer is strongly affected upon the inclusion of 2,4-dihydroxyquinoline in the nano cavities of cyclodextrin derivatives. Molecular encapsulation of 2,4-dihydroxyquinoline by $\square-, \square$, and methyl $\square$ cyclodextrins in aqueous media has been studied by steady state absorption and fluorescence emission techniques. It has been found that the fluorescence intensity at 360 $\mathrm{nm}$ increases in case of inclusion in $\square-\mathrm{CD}$. On the other hand, the band at $360 \mathrm{~nm}$ decreases with concomitant increase of the fluorescence intensity at about $325 \mathrm{~nm}$ in case of the inclusion in $\square-\mathrm{CD}$ and $\mathrm{M} \square-\mathrm{CD}$. Calculation of the association constant shows that inclusion in $\square$-CD is higher than in case of $\mathrm{M} \square-\mathrm{CD}$ and $\square$-CD
\end{abstract}

Keywords: Hydroxyquinoline, Inclusion complexes, cyclodextrins, spectrophotometry, Benesi-Hildebrand

\section{Introduction}

Hydroxyaromatic compounds show remarkable changes in their acidity upon excitation to their first electronic excited singlet state and become stronger acid than in their ground state. The phenomena of increased acidity upon electronic excitation, is called photoacidity and the molecules are termed photoacids (Alazaly 2018, Pines 2007). A series of 2-naphthol derivatives with cyano group at different positions on the distal ring have reported to have $\mathrm{pK}_{\mathrm{a}}^{*}$ values lower than for 2-naphthol itself and therefore called these derivatives "super photoacids" (Tolbert 2002). These authors have also reported naphthol derivatives with electron-withdrawing groups such as cyano or methanesulfonyl at C-5 and C-8 and found that they exhibit greatly enhanced photoacidity that enables excited state proton transfer (ESPT) to non-aqueous solvents such as alcohols and $\mathrm{Me}_{2} \mathrm{SO}$ (Tolbert 1994). Agmon showed that the proton transfer step itself, which occurs in picoseconds, appears to depend crucially on the solvent due to the dependence of the dissociation rate parameter on water concentration and temperature. The dissociated proton diffuses in aqueous solutions anomalously fast, each proton hop taking place in just 1-2 ps (Agmon 2005).

*Corresponding author: Hesham.Abdel-samad@sci.asu.edu.eg, 
Photoacids other than naphthol derivatives have been recently reported as highly photostable "super"-photoacids (Finkler 2014).

Cyclodextrins (CD's) are shaped like a truncated cone polysaccharide made up of six to eight D-(+) glucopyranose monomers connected at the 1 and 4 carbon atoms. The cavities of CD's are relatively hydrophobic and have an internal diameter of 4.7-8.3 A ${ }^{\circ}$ (Szejtli 1998). This difference in cavity size allows binding specificity to be tailored based on substrate size and geometry (Breslow 1998). It is known that cyclodextrins (CDs) have the property of forming inclusion complexes with guest molecules with suitable characteristics of polarity and dimension. This ability has been widely used in studies of general inclusion phenomena and enzyme-substrate interactions, applied in food and pharmaceutical industries (Kida 2008), and has also been used for analytical purposes (Sá Couto 2018).

The important feature of hydroxyquinolines is that they can exist in keto and enol tautomeric forms ( $\mathbf{K}$ and $\mathbf{E}$ ) and also, depending on the acidity of solution, undergo protonation and deprotonation reactions. Photochemical excitation often results in the alteration of acidity of protropic functional groups, which causes the shift in tautomeric equilibrium.

Although a large number of systems are capable of forming inclusion complexes with $\mathrm{CDs}$, the changes in the photophysical properties on encapsulation are, in many cases too small to provide any meaningful and reliable information on the micro-heterogeneity of the $\mathrm{CD}$ or the location of the probe. This necessitates further studies of the complexation processes involving probes whose photophysical properties are sensitive to any change in the environment. In the majority of inclusion complexes with cyclodextrin derivatives, changes in the fluorescence of the guest compounds were used to study the formation constants while changes in the ground state were minimal. We have recently examined the effect of inclusion on the intramolecular excited state proton transfer for different 1-naphthol and 2-naphthol derivatives and found that changing the substituent position has clearly affected the emission characteristics of the host. Fluorescence emission measurements were used to determine the association while the changes in the absorption spectra were too weak to follow the inclusion process (Amer 2019, Abdel-Shafi 2009, Abdel-Shafi 2007).

In this study inclusion of 2,4-dihydroxyquinoline as a photoacid (Scheme 1) in $\square-, \square$, and methyl $\square$-cyclodextrins in aqueous media are investigated by steady state measurements. Effect of inclusion on the deprotonation from 2,4-dihydroxyquinoline upon inclusion in $\square$-, $\square$, and methyl $\square$-cyclodextrins will be investigated. Association constants of complex formation between 2,4-dihydroxyquinoline and $\square$-, $\square$, and methyl $\square$-cyclodextrins are to be determined.

\section{Experimental}

2,4-Dihyroxyquinoline (DHQ) was obtained from Aldrich and recrystallized from ethanol. $\square-, \square$, and methyl- $\square$-cyclodextrins were obtained from Aldrich and used as received (Scheme 2). Deionized water with resistivity $>10 \mathrm{M} \Omega / \mathrm{cm}$ and $\mathrm{pH}$ of 6.8 was used. DHQ stock solution $(2 \mathrm{mM})$ was prepared by dissolving the appropriate amount of DHQ in water, and 0.1 $\mathrm{ml}$ of this solution was transferred into $10 \mathrm{ml}$ volumetric flasks and diluted with different 
concentrations of cyclodextrin derivatives. All experiments were performed at room temperature $\left(25^{\circ} \mathrm{C}\right)$. Concentration of cyclodextrin derivatives were around $0.1 \mathrm{mM}$ to maximum solubility (about $10 \mathrm{mM}$ ). Absorption spectra were recorded on Shimadzu 1800UV-Visible spectrophotometer. Steady state fluorescence measurements were obtained using Thermo Scientific Lumina spectrofluorophotometer.<smiles>Oc1cc(O)c2ccccc2n1</smiles>

Scheme 1: 2,4-Dihydroxyquinoline (DHQ)

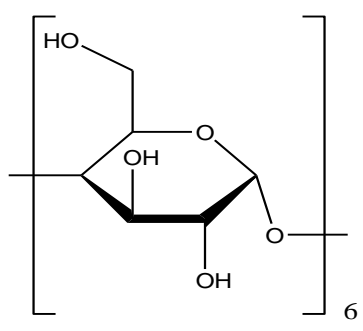

$\alpha$-cyclodextrin

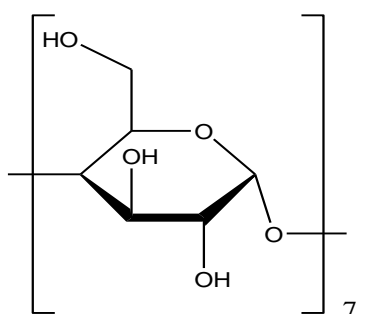

$\beta$-cyclodextrin

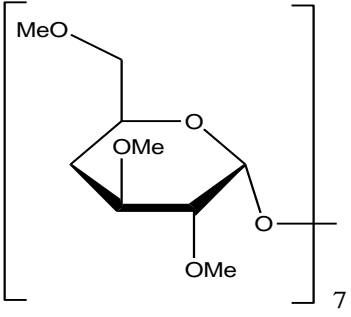

Methyl- $\beta$-cyclodextrin

\section{Results and Discussion}

Scheme 2 .

Figure 1 shows the absorption spectra of DHQ in aqueous solution containing various concentrations of $\square$-CD. When $\square$-cyclodextrin is added to DHQ, the absorbance at $290 \mathrm{~nm}$ shows the maximum decrease in the absorbance with two diffuse isosbestic points at 260 and $300 \mathrm{~nm}$. The absorption spectral changes indicate the formation of inclusion complex between DHQ and $\square$-cyclodextrin.

For 1:1 inclusion complex formed between DHQ and $\square-\mathrm{CD}$, the equilibrium can be written as:

$$
\mathrm{DHQ}+\square-\mathrm{CD} \rightleftharpoons \mathrm{DHQ}-\square-\mathrm{CD}
$$

The association constant can be determined according to the early well known BenesiHildbrand relation [Bensi 1949] for a 1:1 host-guest complex:

$$
\frac{1}{\Delta \mathrm{A}}=\frac{1}{\Delta \varepsilon}+\frac{1}{\mathrm{~K} \Delta \varepsilon[\beta-\mathrm{CD}]}
$$

where $\square \mathrm{A}$ is the difference between the absorbance of DHQ in the presence and absence of $\square-\mathrm{CD}, \square \square$ is the difference between the molar absorption coefficient of DHQ and the inclusion complex and $\mathrm{K}$ is the association constant. 


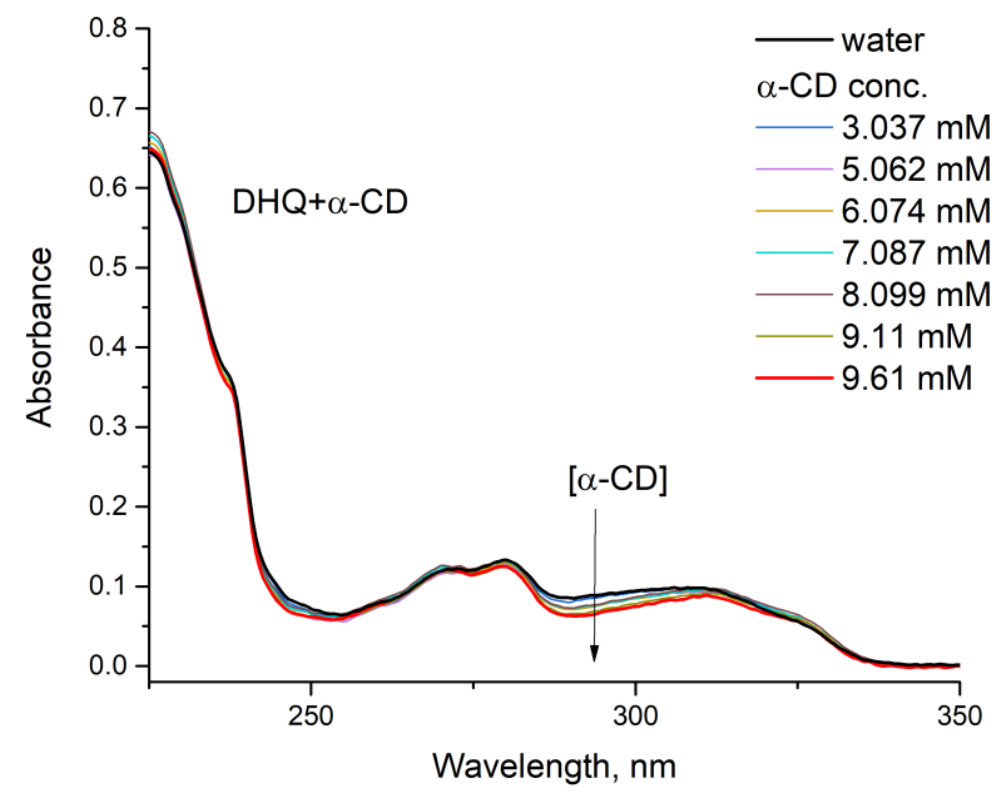

Figure 1. The absorption spectra of DHQ in aqueous solution and different concentrations of $\square$-cyclodextrin (from zero to $9 \mathrm{mM} \square-\mathrm{CD}$ ).

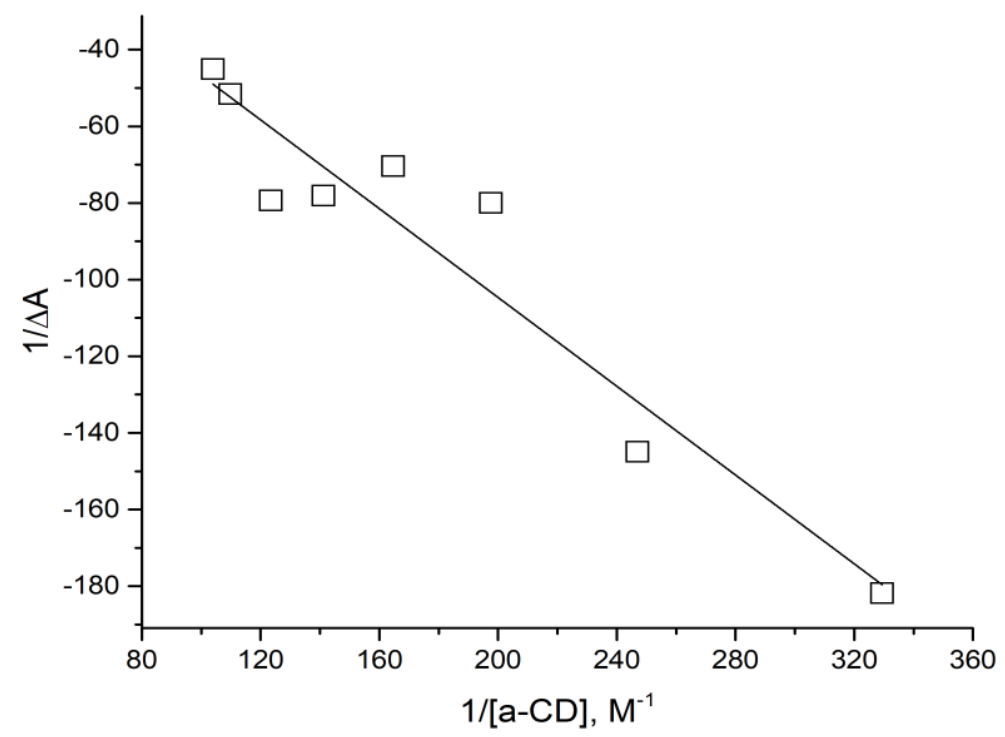

Fig. 2: The Benesi-Hildbrand plot of 1DA vs 1/[ $\square-C D]$, data taken from Fig. 1.

A linear plot (Fig. 2) is obtained according to Eq. 2 which suggests that DHQ- $\square-C D$ inclusion complex has a 1:1 stoichiometry. The association constant, $\mathrm{K}$, for the formation of the inclusion complex is determined from the ratio of intercept to slope in the linear BenesiHildbrand plot and found to be $19.4 \pm 5 \mathrm{M}^{-1}$. 


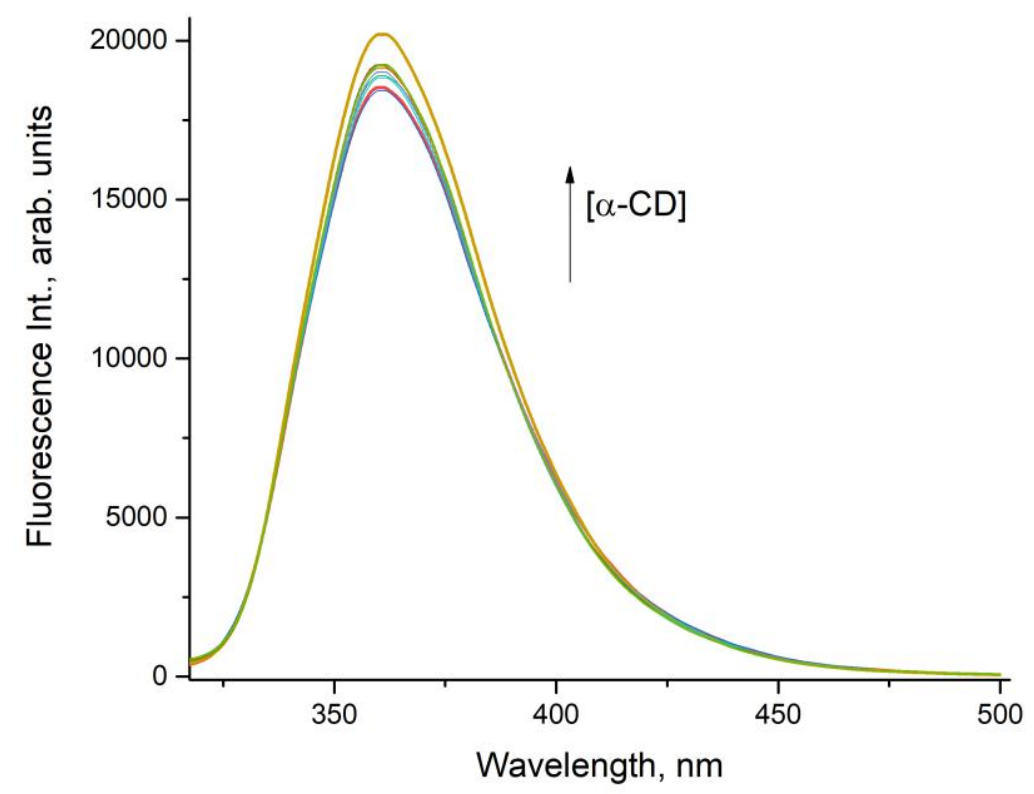

Figure 3. The fluorescence emission spectra of DHQ in aqueous solution and different concentrations of $\square$ cyclodextrin ( $\square$-CD concentrations as given in Fig. 1), $\square_{\mathrm{ex}}=280 \mathrm{~nm}$.

The effect of addition of $\square$-CD on the fluorescence spectra of DHQ has been found to be similar to the corresponding effect on the absorption spectra (Fig. 1). The fluorescence band intensity at $360 \mathrm{~nm}$ decreases upon the increase of $\square$-CD concentrations, with an isoemissive point at $390 \mathrm{~nm}$. This behaviour can be attributed to the decrease in the rate of deprotonation from DHQ which may be attributed to the inclusion of DHQ in a more hydrophobic environment within $\square$-CD cavity which lead to a change in water cluster structure of $\left(\mathrm{H}_{2} \mathrm{O}\right)_{4 \pm 1}$ necessary for proton transfer process.

Data in Fig. 3 can be treated using Benesi-Hildbrand equation for 1:1 binding model using the following equation:

$$
\frac{1}{I_{\mathrm{f}}-I_{\mathrm{f}}^{0}}=\frac{1}{I_{\mathrm{c}}-I_{\mathrm{f}}^{0}}+\frac{1}{\mathrm{~K}\left(I_{\mathrm{c}}-I_{\mathrm{f}}^{0}\right)[\mathrm{CD}]}
$$

where $I_{\mathrm{f}}^{0}$ and $I_{\mathrm{f}}$ are the fluorescence intensity in the absence and presence of $\square-\mathrm{CD}$, respectively. $I_{\mathrm{c}}$ is the fluorescence intensity of the DHQ-CD complex and $\mathrm{K}$ is the association constant for DHQ- $\square-\mathrm{CD}$ complex. According to Eq. (3), a plot of $1 /\left(I_{\mathrm{f}}-I_{\mathrm{f}}^{0}\right)$ versus $1 /[\square-\mathrm{CD}]$, gives a straight line (Fig. 4) from which $\mathrm{K}$ value was found to be $385 \mathrm{M}^{-1}$. The obtained linearity of the plot confirms that 1:1 inclusion complex is formed between DHQ and $\square-\mathrm{CD}$. The large increase in the association constant obtained from fluorescence measurements is a consequence of better inclusion of the anionic form of DHQ which is a result of the excited state proton transfer to the solvent (water in this case). 


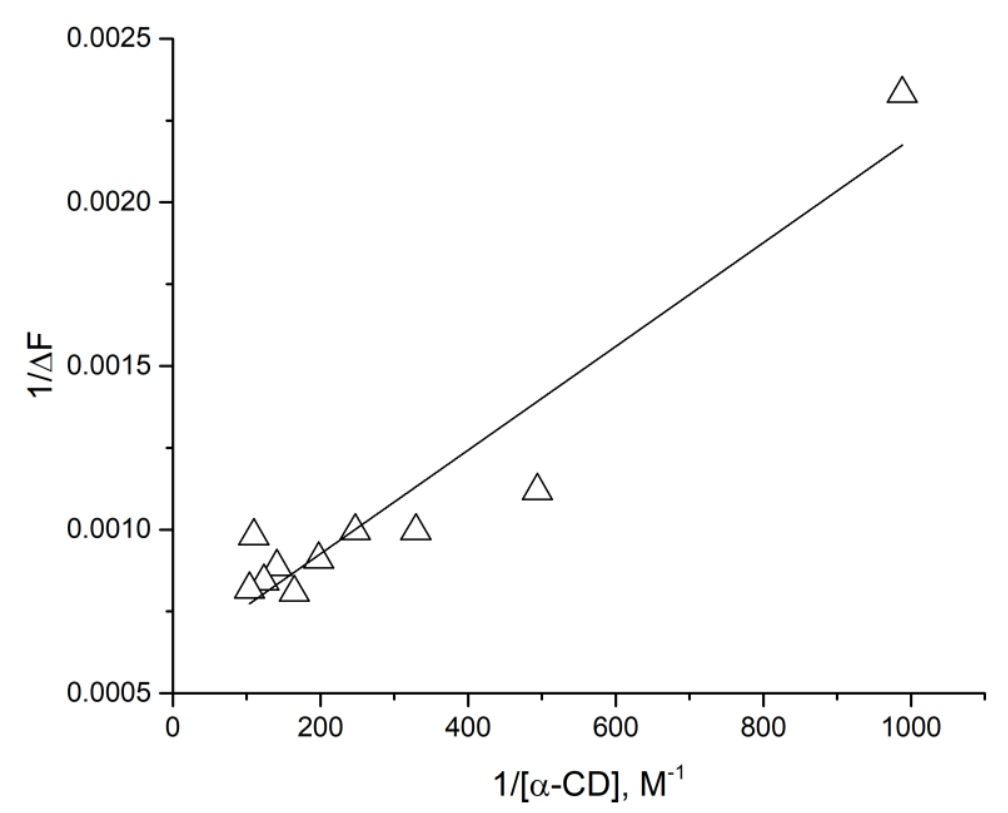

Figure 4. The Benesi-Hildbrand plot of $1 /(\square \mathrm{F})$ vs $1 /[\square-\mathrm{CD}]$

Addition of different concentrations $\square$-CD from 0 to $9.5 \mathrm{mM}$ results in small changes in the absorption spectra with major change at $290 \mathrm{~nm}$ as the absorbance decreases with the increase of $b-C D$ concentrations. However, application of equation 2 to the observed changes as shown in Fig. 5 was not successful.

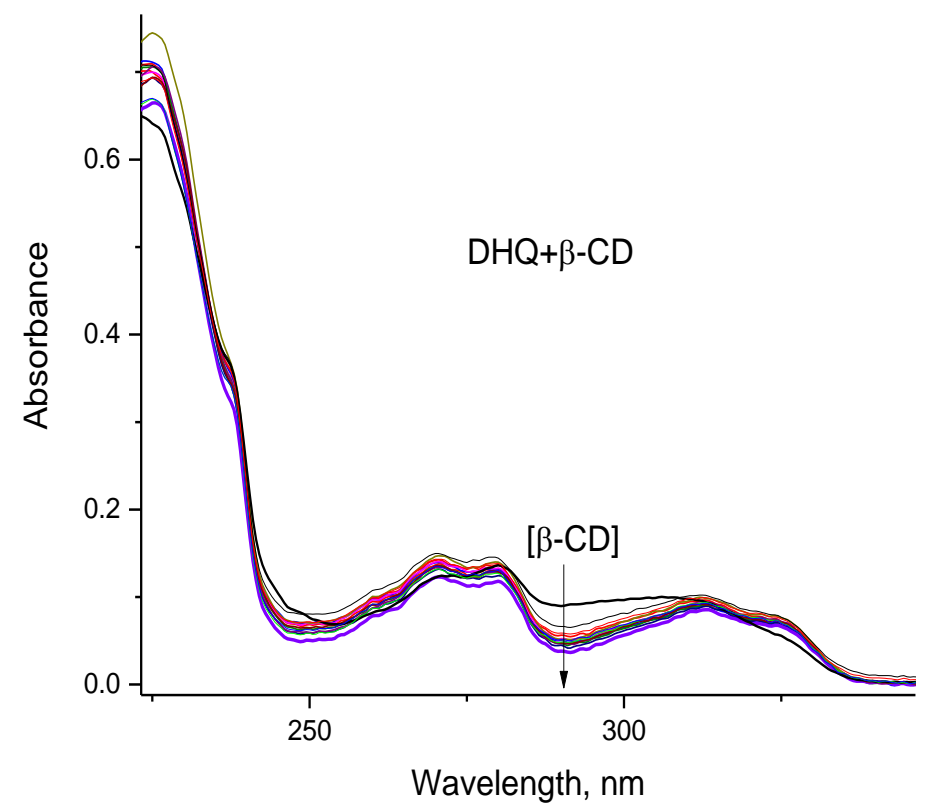

Figure 5. The absorption spectra of DHQ in aqueous solution and different concentrations of $\square$-cyclodextrin (from zero to $9.0 \mathrm{mM} \square-\mathrm{CD}$ ). 


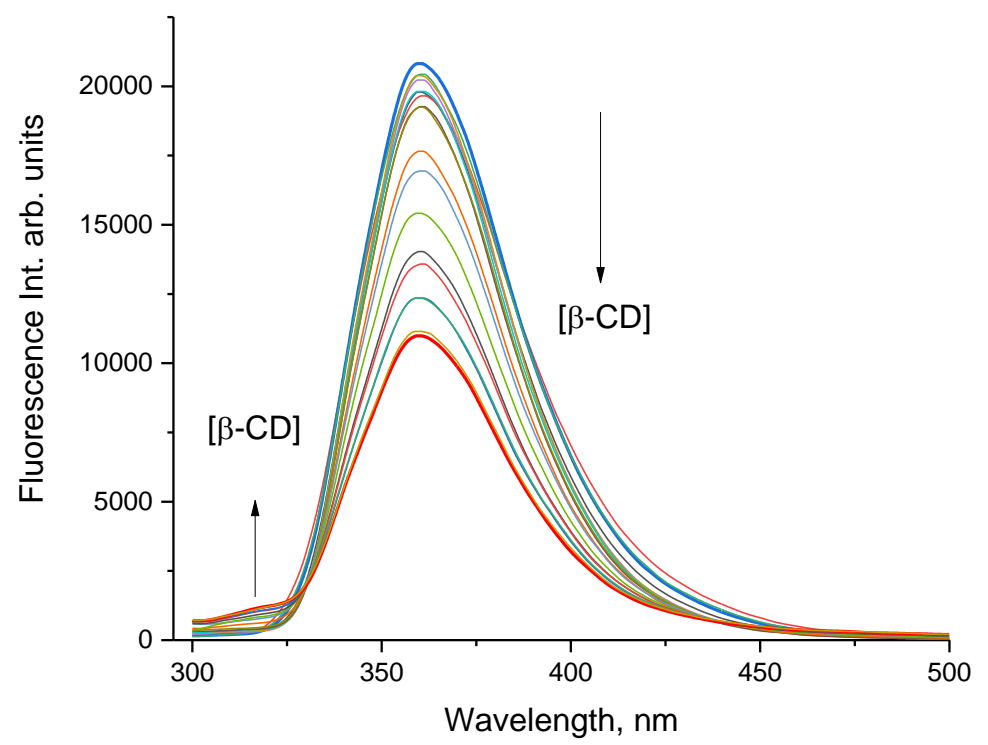

Figure 6. The fluorescence emission spectra of DHQ in aqueous solution and different concentrations of $\square$ cyclodextrin (from zero to $9.0 \mathrm{mM} \square-\mathrm{CD}$ ) $\square_{\mathrm{ex}}=280 \mathrm{~nm}$.

On the other hand, addition of different concentrations of $\square$-CD to the aqueous solution of DHQ results in a pronounced change in the fluorescence emission spectra with an iso-emissive point at $327 \mathrm{~nm}$, which point to a major change in the deprotonation of DHQ with different concentrations of $\square$-CD. Application of Eq. 3 to the data in Fig. 6 is shown in Fig. 7 which is only linear in the range of high concentrations of $\square$-CD. From the slope and intercept of Eq. 3, as association constant of $450.0 \pm 50 \mathrm{M}^{-1}$ was obtained for the inclusion of DHQ inside the cavity of $\square-C D$.

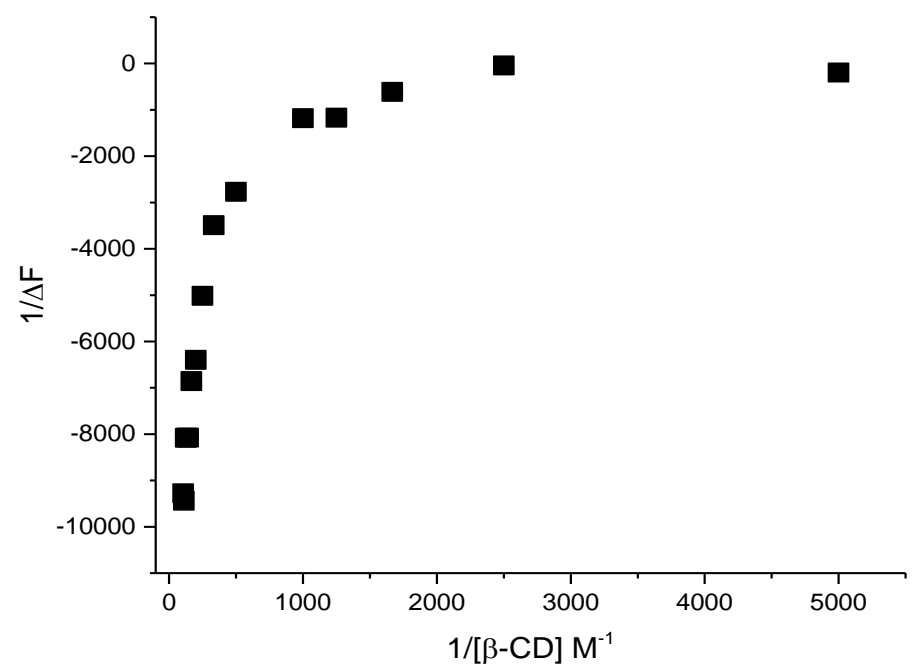

Fig. 7: Plot according to Eq. 3 for the effect of $\square-\mathrm{CD}$ addition to the aqueous solution of DHQ.

Finally, addition of different concentrations of $\mathrm{Me} \square$-cyclodextrin to the aqueous solution of DHQ shows weak changes in the absorption spectra (Fig. 8) that did not allow for 
the determination of the association constant from these data. On contrast to the clear changes observed in case of $\square-C D$, changes in the fluorescence emission spectra (Fig. 9) with $\mathrm{M} \square-\mathrm{CD}$ was found to be similar to that observed with $\square$-cyclodextrin and clear isoemissive point at $337 \mathrm{~nm}$ which is about $10 \mathrm{~nm}$ red shifted relative to that observed for the inclusion of DHQ in $\square-\mathrm{CD}$ that could be explained due to the equilibrium difference in both cases. Application of Eq. 3 to the data given in Fig. 9, results in an association constant of $63.0 \pm 10$

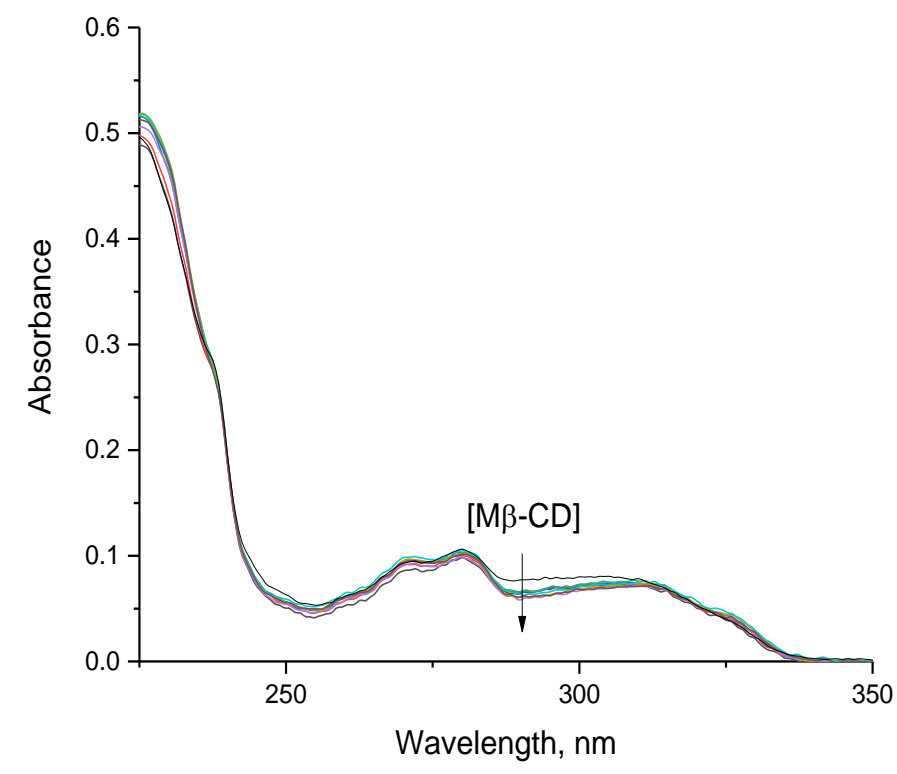

Figure 8. The absorption spectra of DHQ in aqueous solution and different concentrations of Me $\square$-cyclodextrin (from zero to $11 \mathrm{mM} \mathrm{Me} \square-\mathrm{CD}$ ).

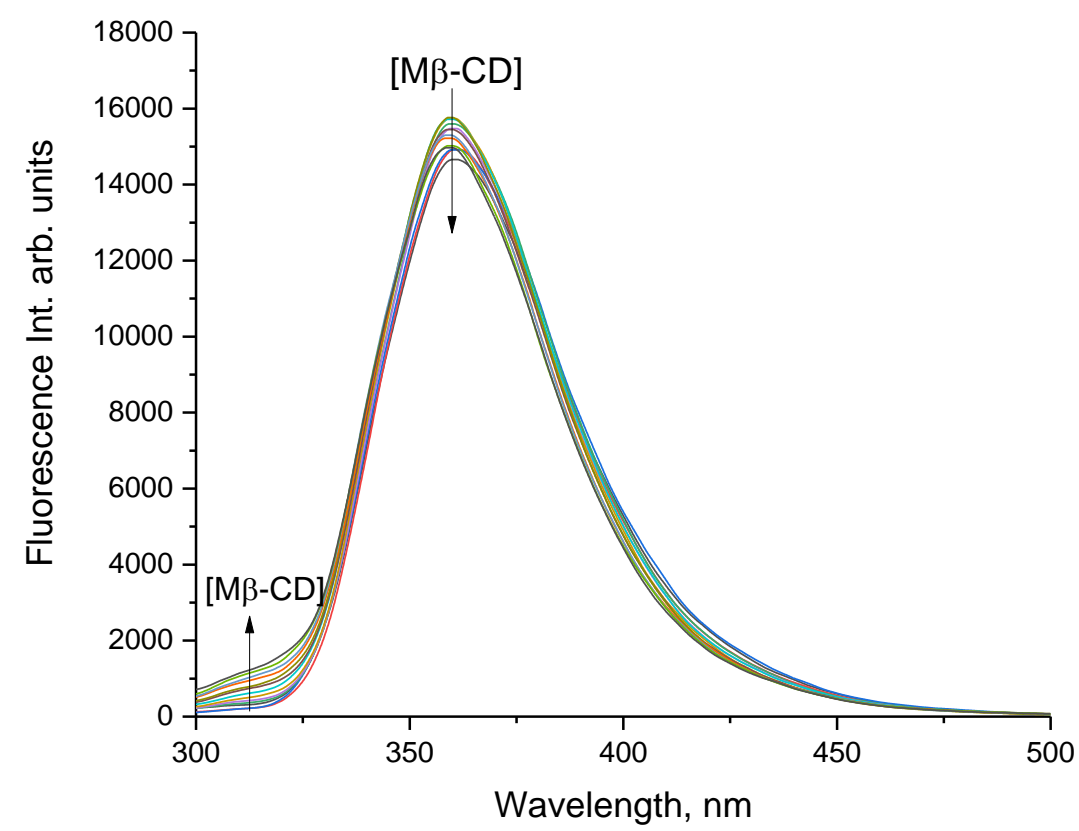

Figure 9. The fluorescence emission spectra of DHQ in aqueous solution and different concentrations of $\mathrm{Me} \square$ cyclodextrin (from zero to $11 \mathrm{mM} \mathrm{M} \square-\mathrm{CD}$ ) $\square_{\mathrm{ex}}=290 \mathrm{~nm}$. 


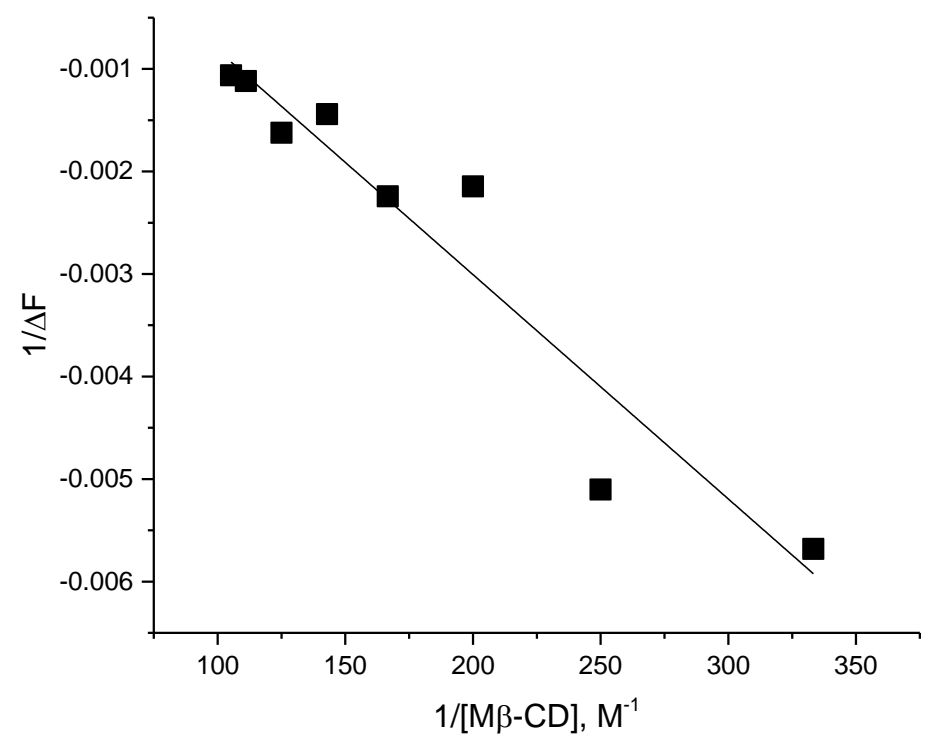

Fig. 10: Plot according to Eq. 3 for the effect of $M \square-C D$ addition to the aqueous solution of DHQ.

\section{Conclusion:}

Inclusion in $\square$-CD, $\square-\mathrm{CD}$ and $\mathrm{M} \square-\mathrm{CD}$ of 2,4-dihydroxyquinoline photoacid was studied by spectrophotometry and spectrofluorometry. It has been found that changes in the absorption were too small to allow for good determination of the association constants. On the other hand, changes in the fluorescence emission spectra were much pronounced. Association constants obtained were $385.0 \mathrm{M}^{-1}, 450.0 \mathrm{M}^{-1}$ and $63.0 \mathrm{M}^{-1}$ in case of the inclusion in $\square-\mathrm{CD}$, $\square-\mathrm{CD}$ and $\mathrm{M} \square-\mathrm{CD}$, respectively. The lowest association constant reported in case of the inclusion in $\mathrm{M} \square-\mathrm{CD}$ was due to steric hindrance of the inclusion in this case due to the presence of the methyl group on $\square$-CD.

\section{References:}

Abdel-Shafi A. A.; Al-Shihry S. S. (2009), Fluorescence enhancement of 1-napthol-5sulfonate by forming inclusion complex with b-cyclodextrin in aqueous solution, Spectrochim. Acta A, 72, 533-537

Abdel-Shafi, A. A. (2007), Spectroscopic studies on the inclusion complex of 2-naphthol-6sulfonate with b-cyclodextrin, Spectrochim. Acta A, 66, 732-738,

Agmon, N. (2005), Elementary Steps in Excited-State Proton Transfer, J. Phys. Chem. A 109, $13-35$

Alazaly A. M. M., Amer A. S. I., Fathi A.M. and Abdel-Shafi A. A. (2018), Photoacids as singlet oxygen photosensitizers: Direct determination of the excited state acidity by timeresolved spectroscopy, Journal of Photochemistry \& Photobiology A: Chemistry 364, 819825 
Amer A. S. I, Alazaly A. M. M., Ayman A. Abdel-Shafi A. A. (2019), Solvatochromism of 1naphthol-4-sulfonate photoacid and its encapsulation in cyclodextrin derivatives, Journal of Photochemistry \& Photobiology A: Chemistry 369, 202-211

Benesi, H. A., Hildbrand, J. H. (1949) A Spectrophotometric Investigation of the Interaction of Iodine with Aromatic Hydrocarbons. J. Am. Chem. Soc. 71, 2703-2707.

Finkler, B.; Spies, C.; Vester, M.; Walte, F.; Omlor, K.; Riemann, I.; Zimmer, M.; Stracke, F.; Gerhards, M.; Jung, G. (2014) Photochem. Photobiol. Sci., 13, 548-562.

Tolbert, L. M.; Solntsev, K. M. (2002), Excited-State Proton Transfer: From Constrained Systems to "Super" Photoacids to Superfast Proton Transfer, Acc. Chem. Res. 35, 19-27.

Tolbert, L. M.; Haubrich, J. E. (1994), Photoexcited Proton Transfer from Enhanced Photoacids, J. Am. Chem. Soc. 116, 10593-10600

Pines D.; Pines, E. (2007) Solvent Assisted Photoacidity, chapter 12, Hydrogen-Transfer Reactions (Vol. 1 Physical and Chemical Aspects I-III, pp 377-415.) Edited by Hynes, J. T.; Klinman, J. P.; Limbach, H. H.; R. L. Schowen Copyright (C) 2007 WILEY-VCH Verlag GmbH \& Co. KGaA, Weinheim, ISBN: 978-3-527-30777-7.

Szejtli, J. (1998), Introduction and general overview of cyclodextrin chemistry. Chem. Rev., $98,1743-1753$

Breslow R., Dong, S. D., (1998) Biomimetic Reactions Catalyzed by Cyclodextrins and Their Derivatives. Chem. Rev., 98, 1997.

Kida, T., Nakano, T., Fujino, Y., Matsumura, C., Miyawaki, K., Kato, E., Akashi, M. (2008) Complete Removal of Chlorinated Aromatic Compounds from Oils by Channel-Type $\gamma$ Cyclodextrin Assembly. Anal. Chem., 80, 317-320.

Sá Couto A. R., Ryzhakov A., Loftsson T. (2018), 2-Hydroxypropyl- $\beta$-Cyclodextrin Aggregates: Identification and Development of Analytical Techniques, Materials, 11, 19711987. 


\section{الملخص باللغة العربية}

"دراسة الخواص الطيفية والاحتواء داخل مركبات السيكلوديكسترين النانوية لمركب ؛ ب ثنائي هيدروكسي كينولين"

هدى محمود عبد الرحمن' ، أحمد محمد العزالي'، هاني هنتر منير'، هشام سمير عبد الصمد'، أيمن أيوب عبد الشافي' هائي

1 : قسم الكيمياء كلية العلوم جامعة عين شمس بالعباسيةـ القاهرة - جمهورية مصر العربية

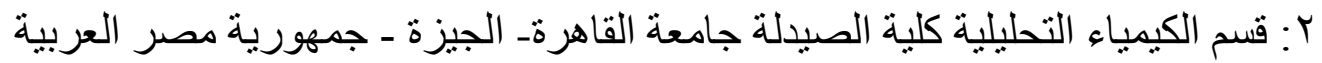

في هذا البحث تم در اسة احتو اء ؟, بـ ثنائي هيدروكسي كينولين داخل مركب سيكلوديكسترين ذو أبعاد احتو اء مختلفة (ألفا، بيتا ، وميثيل بيتا سيكلوديكسترين). وقد تمت هذه الدر اسة باستخدام تقنيتي قياس اطياف الامتصاص الضوئية و الانبعاث الفلوريسينى.

أظهرت قياسات الحالة الأرضية للمركبات المحضرة حدوث تغييرات طفيفة جدا في أطياف الامتصاص لهذه المركبات عند إضافة الأنواع المختلفة من مشتقات السيكلوديكسترن والتي لم تسمح بتعبين ثابت التر ابط بينهم.

في حين لوحظ تغييرات أكثر وضوحا في أطياف الانبعاث نتيجة إضافة مشتقات السيكلوديكسترين ذات احجام الاحتو اء المختلفة لمركب الهيدروكسي كينولين. 